\title{
Megadome Evolution in The Ottoman's Mosques; The Links
}

\author{
Noor Cholis Idham ${ }^{1}$ and Ibrahim Numan ${ }^{2}$ \\ ${ }^{1}$ Department of Architecture, Universitas Islam Indonesia, Yogyakarta Indonesia \\ ${ }^{2}$ Faculty of Architecture, Fatih Sultan Mehmet University, Istanbul Turkey \\ 1*noor.idham@uii.ac.id
}

Published: $31^{\text {st }}$ December 2020

\begin{abstract}
A long history of civilization through various cultural and technological influences, had shaped the Ottoman mosque architecture. Each of the objects has its unique characteristics yet connected each other. This paper examines how the classic Turkish mosque-dome architecture, have evolved by proposing examination on configuration similarities and its connection. The authors address 23 mosques in the high classical period of the Ottoman's era to reveal spatial and technical considerations of the main building. The dynasty's route in architecture from central Asia, Seljuk, Bursa, Edirne, and Istanbul is the context of the discussion. It is undeniable that the development of dome architecture in classical Turkey shows some clear linkages from the previous to the later age. Furthermore, some links connected pre and after Istanbul conquest, which contribute to clarify the dispute of the novelty of the architecture, were discovered.
\end{abstract}

Keywords: Ottoman mosque, Dome structure, Islamic architecture, Architectural evolution 


\section{BACKGROUND}

Mosque architecture in Islamic society holds a very significant role to glory the name of God and to spread the teaching of His unity as Tauhid, which had been experienced in every aspect of life Since its beginning, although it may start in a simple form, the mosque in the early time was already in rich decoration (Johns, 1999). It is not true that a mosque was seen without the certainty of spatial sacred and did not involve aesthetic and architectural creativity (Taib \& Rasdi, 2012). Through the development of Islamic civilization, mosques became the most artistic and magnificent architecture. In the Ottoman time, the role of the greatness of mosques was not decently as a reflection of the importance of country and the ruler but constitutively serves the conception of "Ila-i Kelimatullah" (to glory the name of Allah), religious activities and bears social as well as political purposes.

Along with the spread of Islam and conquest of the new vast-variety areas, the mosque then much developed (Mustafa \& Hassan, 2013). The achievement of a better economy, science, technology, and the advent of materials, as well as the governmental determination, evolve into a complicated dome architecture with a higher level of aesthetical as well as technical understanding. To realize the importance attributed to the dome in Ottoman architecture, besides the relationship between the centralized, unifying characteristics of the dome and the unity in Muslim thought, the background of the Turkish mosque architecture, the roots, key figures, and the importance of Istanbul should be well understood.

\subsection{Domes in the Ottoman's Mosque history}

A long struggle had been initiated when one of The Prophet's companion and Standard bearer Ayyub Al-Anshari (Eyüp Ensari) tried to conquer Constantinople at the first wave in the 670s AD. He died in 672 in the second war and was buried near to the city wall. More than 750 years after, when Sultan Muhammad II the Conqueror or Fatih Sultan Mehmet finally accomplished the mission in 1453 , one of the first considerations was to build the mosque outside the city's wall where Al-Anshari had been buried in commemoration to him as a spiritual leader and hero (Gamm, 2014). Eyüp Sultan Camii (1458-59) is the first mosque in Istanbul and became one of the most important places to the empire, such as for the sultan coronation. Five years later, Fatih Camii (1463-1470) was built as the first Salatin Camii or sultan's mosque in Istanbul. Unfortunately, these two early Istanbul mosques were collapsed by earthquakes and rebuilt with different architecture.

The Ottoman mosques are identic with the dome configuration, which is unique to each other and always context to the time and place. The architecture, as broadly known, has a dual origin; Islam and East Roman or Byzantine (Kuban, 1985). It is also discussed that the origin extends up to pre Islamic Central Asian Turkish related to the central space understanding (Numan, 1982). The sources of dome utilization in Ottoman Architecture laid back to the Karakhanids period (840-1212) in Central Asia as the first Muslim Turkish dynasty (Karamağaralı, 2002; Sözen, 1975). Central Asia, Iran, and Mesopotamia are the places where earthen architecture reaches its peak, and Seljuk was the uttermost of the brick structure, including vault and dome (Kuban, 1985). A central dome in the cross of four sides Iwan was the main characteristic of mosque inspired by the Turk traditional house. Ghaznavids dynasty (977-1186) was also another resource of the architecture characterized by a single dome and bulk of columns. Seljuk's mosques by Seljuk Dynasty (1037-1194) then enlarged the space by serial columns arrangement known as hypostyle hall completed with courtyard, four iwans, and a dome in front of the mihrab. A similar configuration, yet with the smaller inner court, the Seljuk-Anatolian mosques then emerged (Karamağaralı, 2002). Along with the geographic and climatic zone adjustment, the enclosed court later adopted inside multi dome configuration in early Ottoman mosques in Bursa and Edirne (see figure 1). 


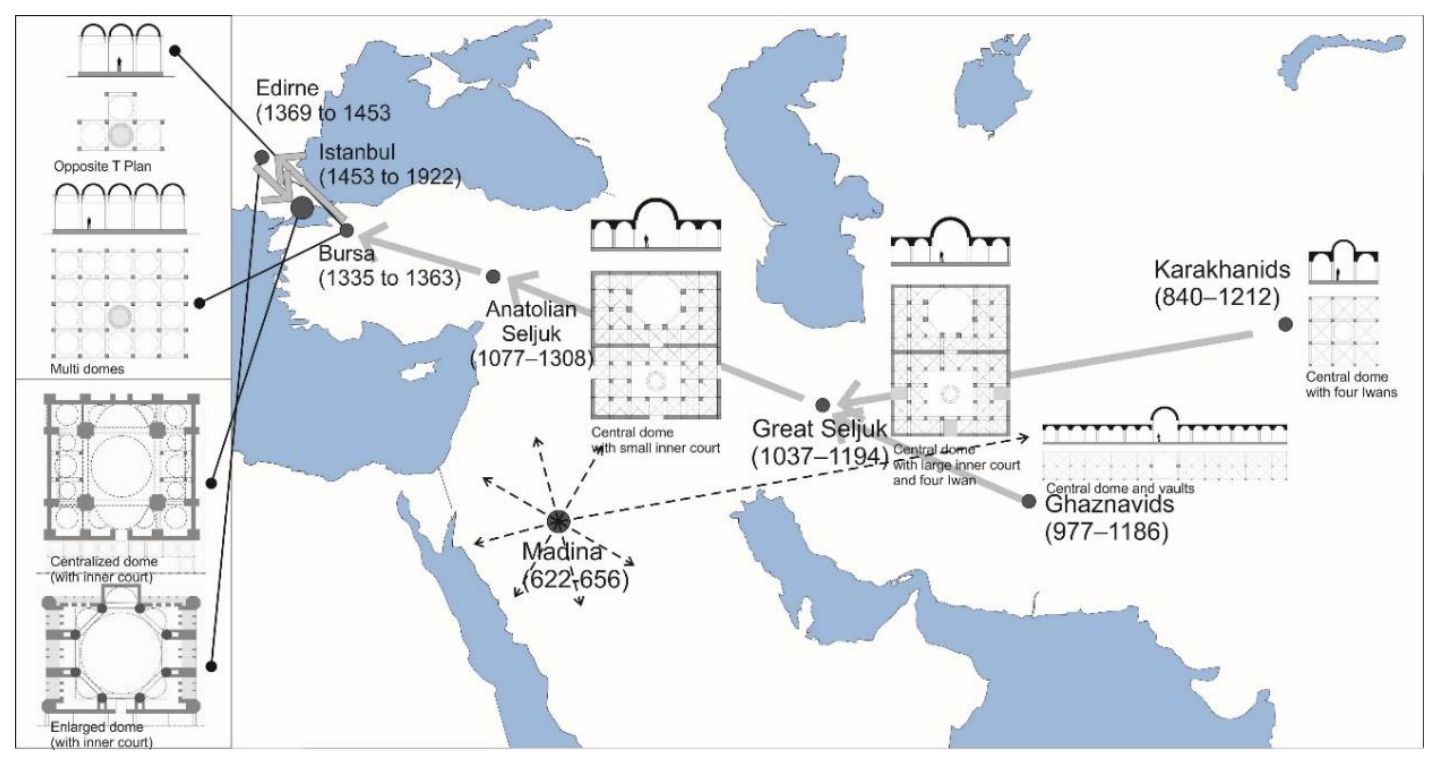

Figure 1. Turk origin and the dome cultures for mosque architecture

They met the remaining edifices and the building technologies of the previous cultures in Anatolia, and soon they reached the territory of East Rome and conquest Constantinople, the architecture was developed accordingly. The repetitive dome met the centralized with or without half dome then characterized most of the magnificent mosques through the empire's periods. The form acculturation is impressive, especially in the early development to the peak of the age of the Ottoman Empire when many impressive mosques been built. Süleymaniye mosque (1550-1557) in Istanbul, as well as Selimiye mosque (1568-1574) in Edirne, are among the greatest Ottoman architectural legacies as a result of the process. Although neither aesthetically nor proportionally reflects the quality of classical Ottoman periods mosques, the Camlica Great Mosque (2019), as the largest mosque in Turkey in the modern-day, is even has been built to the resemblance the greatness of the Ottoman architecture.

As one of the most exciting topics in architecture, many scholars are mastering the Ottoman mosque studies. Ayverdi, Kuban, Kuran, and Sözen are among others who their work became conspicuous to the later relevant researches. Kuran discovered the architectural development in detail from the $13^{\text {th }}$ Century to 1506 when the dynasty reached the immensity (Kuran, 1968). Ayverdi, Sözen, and Kuban researched the mosque in context to the Ottoman architecture evolution in the broader range (Ayverdi, 1953; Kuban, 2007; Sözen, 1975). Güngör, on his investigation of Sinan's practices, focused on the dome structure and divided it into the three domes supporting system as square, hexagonal, and octagonal frames. He focused on the form and construction system of the central dome, which a part of the main prayer hall (Fahjan \& Keypour, 2006; Güngör, 1987). Necipoğlu explained broadly every single work of Sinan. She also grouped the mosques on three configurations; square, hexagonal, and octagonal baldachins and suggest the dome evolution from zero to unique, double, triple, and quadruple half domes (Necipoğlu, 2005). The other researchers have also rediscovered the general distinctions of the architecture, such as Saoud (Saoud, 2004). Mustafa revealed the six dome layouts; single, earring, multiple, duplication-rectangular, courtyard, and earring courtyard. He included the secondary structure, which is the courtyard section (Mustafa \& Hassan, 2013). The author has also already examined the Ottoman's legacies from the 23 buildings in many functions and touched roughly the dome configuration (Idham, 2017). However, paying attention to how the evolution of the primary structural system started and reached the top and settled as a paternal formation still need more elaborated study since some aspects or link might be missed from the previous examinations. 


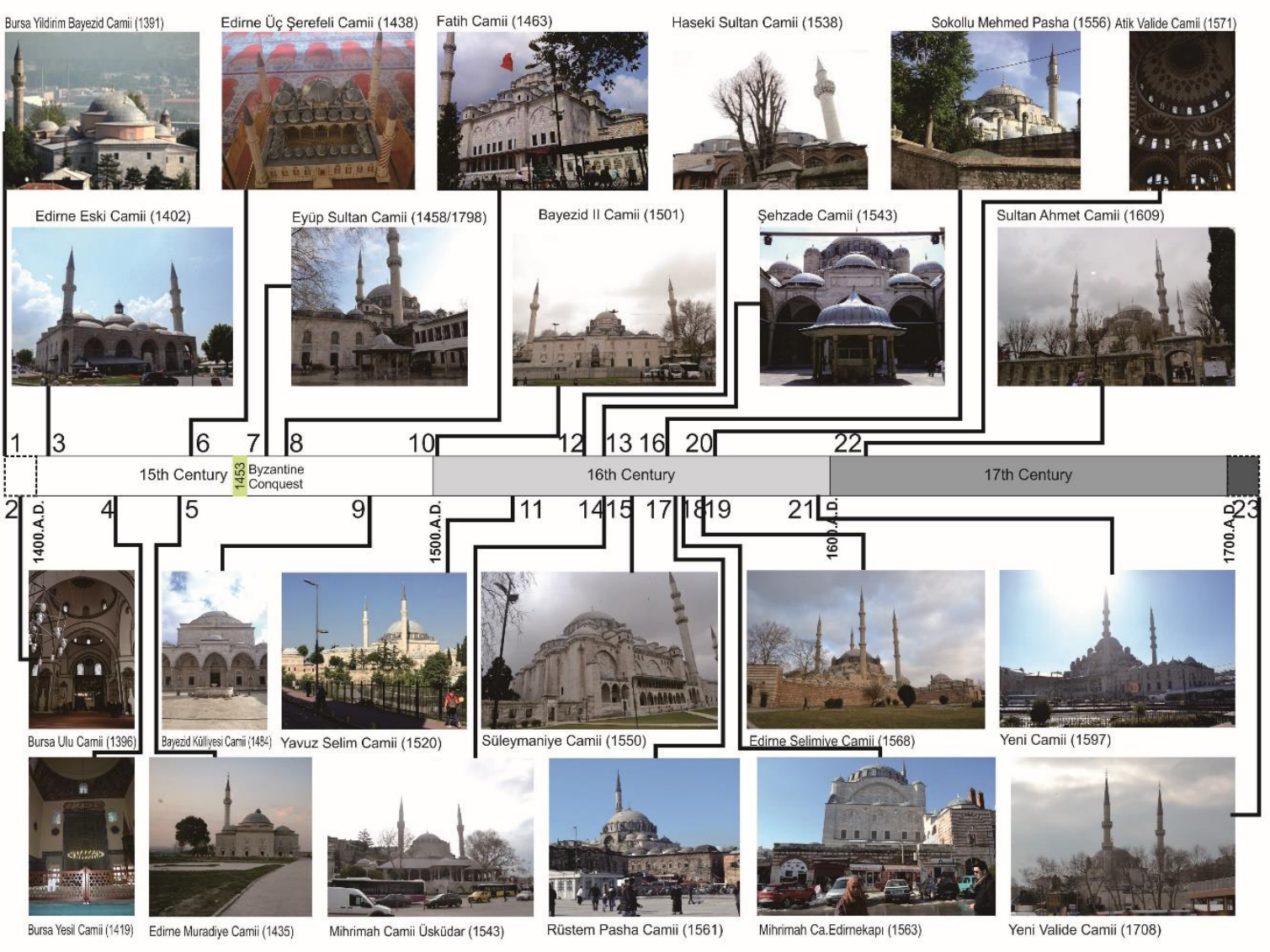

Figure 2. The Ottoman royal mosque development for three centuries from Bursa, Edirne, and Istanbul

Among others related to the architecture, the dome configuration is fascinating since its purpose is not only making the main space but also contributing monumentality. Istanbul period then became the most spectacular dome architecture with a countless variety of configuration, which was never found before. Istanbul is a melting point where civilization reached a peak, and architecture offered the best technique from available sources. The Karahanid and Seljukid architectural tradition brought by the Ottoman trough Anatolia had met with the $6^{\text {th }}$ Century monuments such as Hagia Sophia inspired the more advanced architecture.

This study addresses more in detail the main prayer hall's structural configuration from prior Istanbul, the conquest, the glory, and the steadiness. Although most of the great architectures were produced at the peak of the Empire by one of the great architects Sinan, the other works have a significant contribution. How the architects carried forward the works before and after takeover periods of Istanbul and are then become an interrelated aspect discussed. To achieve the aims, we observe 23 mosques commissioned by the Ottoman Dynasty throughout the periods on Bursa, Edirne, and Istanbul were accessed to determine the typical structure and examine them based on the evolution progress (figure 2). Other buildings, such as churches and other mosques, were used as a comparison to support the argumentation. Charts and schematic drawings were used as the analytical tools to discuss the issues. 


\section{FINDING AND DISCUSSION}

\subsection{Dome structural system}

It is known that the arch has been invented by humankind to accommodate a larger space when it was impossible using flat solid materials. A dome as a three-dimensional arch by rotating it in 360 degrees is the most effective technique to span a space with the small unit but heavy materials such as stones and bricks. It thus became a popular method representing many civilizations starting from Roman, Byzantine, Seljuk, Ottoman, Renaissance, to Baroque (Reyhan, İpekoğlu, \& Böke, 2013). The Pantheon (126), Hagia Sophia (537) Florence Catedral (1436), Selimiye mosque (1568), and Saint Peter's Catedral (1626) are among the most magnificent architectures employing domes. Each of those great buildings has its dome characteristics that might be completely different than others. Nevertheless, the domes in the Ottoman era were much dominating the architectural discourses since it was broadly used for thousands of buildings, not only the mosque, but also the school, hospital, bath, tomb, and others.

The complete configuration of the Ottoman mosque comprises the main prayer hall, which is mostly achieved by the centralized-main dome or series of domes supporting by arches and columns systems, the enclosed courtyard with a fountain (şadırvan), and the boundary arcades (revak). The minaret stands up to one corner of the building for an ordinary mosque and two or more for the dedicated sultan. A mosques complex or kulliye might be added surrounding consists of schools (medrese), health services (darüşşifa), tomb (türbe), market (arasta), caravanserai (han), Turkish bath (hammam), public kitchen (imaret), recovery facility (tabhane), and guest house (misafirhane). All the facilities are mostly under the roof either by a singular or plural dome on the main structure and repetitive dome on the other facilities.
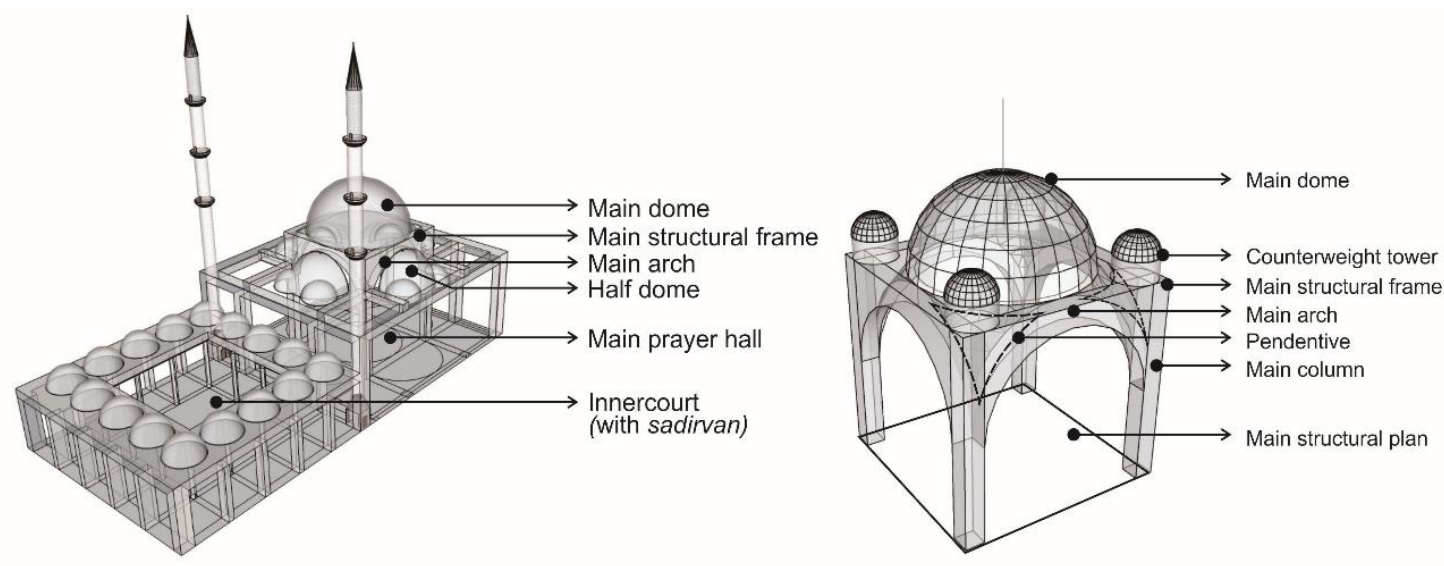

Figure 3. The Ottoman mosque's elements and the primary structural system

The dome is rarely used in a standalone component without the combination of walls, columns, arches, and other domes. As a roof part, a dome needs the supporting system below both for bearing its mass and creating a functional space. A dome structural system consists of the dome itself, supported by arches and several columns with or without the walls, pendentives as transitions elements, counterweight towers, buttresses, columns, walls, and foundations. Three formal supporting systems with rectangular, hexagonal, or octagonal frames were used for structural typology and classification (Fahjan \& Keypour, 2006; Kuban, 2007; Kuran, 1968; Necipoğlu, 2005). The circular base of the dome connects the columns on a quadrangle or hexagonal column-plan by the pendentives (figure 3). For an octagonal base, they are usually thinner or even absent since it will nearly fit the columns and arches below. 


\subsection{Bursa Mosques}

Bursa period (1335 to 1363) was the beginning of the Sultanate as well as the architecture, which was developed further from the Anatolian Seljuk. The main character of the previous architecture is a large hall with a series of vaults roofs, arches, columns, and a central open space completed with four side iwans. The Anatolian courtyard represents back to the Great Seljuk mosque though the size is shrinking. A dome is mostly in front of mihrab combined with the iwan and conical or multi-edge cupola covers outside.

Nonetheless, Bursa mosques are slightly different in terms of adopting the courtyard. The presence of yard and iwans is compacted inside of the hall. A configuration of the double dome with two wing-domes as the $\mathrm{T}$ type or wings type and multi-dome typologies or hypostyle were used. Mosques utilize a single level roof layer with repetitive dome organizations either supported directly by walls for smaller mosques or by several columns and arches for a grand mosque. Although the span of Capital Bursa was short, the evolution of the dome already initiated with Yildirim Bayezid Cami (1391), Bursa Ulu Camii (1396), and Yesil Cami (1419) which distinct the previous mosque architecture.

The Yildirim Bayezid and Yesil Cami are similar in the formation with the opposite T-shape plan covered by two domes for the main prayer hall and inside the courtyard. Two other secondary domes are beneath both side chambers known before as iwan. The left and right wings, as well as the front and center arches, borrowed Seljuk madrasa characteristics and further became the unique $\mathrm{T}$ plan known as the Bursa type (Kuran, 1968). The biggest dome resides in the centerfront area, and a couple of small domes stand on the right and left wings. Under the other big dome on the back laid the mihrab-front space. The central arch, combined with the elevated floor that separates the prayer hall and other arches represent the iwans on the other sides are the most characteristic of the interior.

Ulu Camii is the grand mosque of Bursa known for the multiple dome arrangement with an enormous number of arches and columns inside. The 20 domes supported by arches and pillars create a rectangular plan with repetitive spaces similar to Seljuk's great mosque atmosphere (figure 4). The courtyard now transformed to be a fountain spot under a transparent dome, and the iwan turned to chambers on its four sides. The massive interior space is brightened up by a dome with a lantern accentuating the space underneath as a shrinking courtyard. Since the roof base stands on the same level, the structural integrity from a lateral force is perfect, but the space inside is flatty. This configuration, however, performs interior and exterior monumentality both by the number and the size of the domes. The minarets help to soar the vertical appearance of the magnificent mosques.
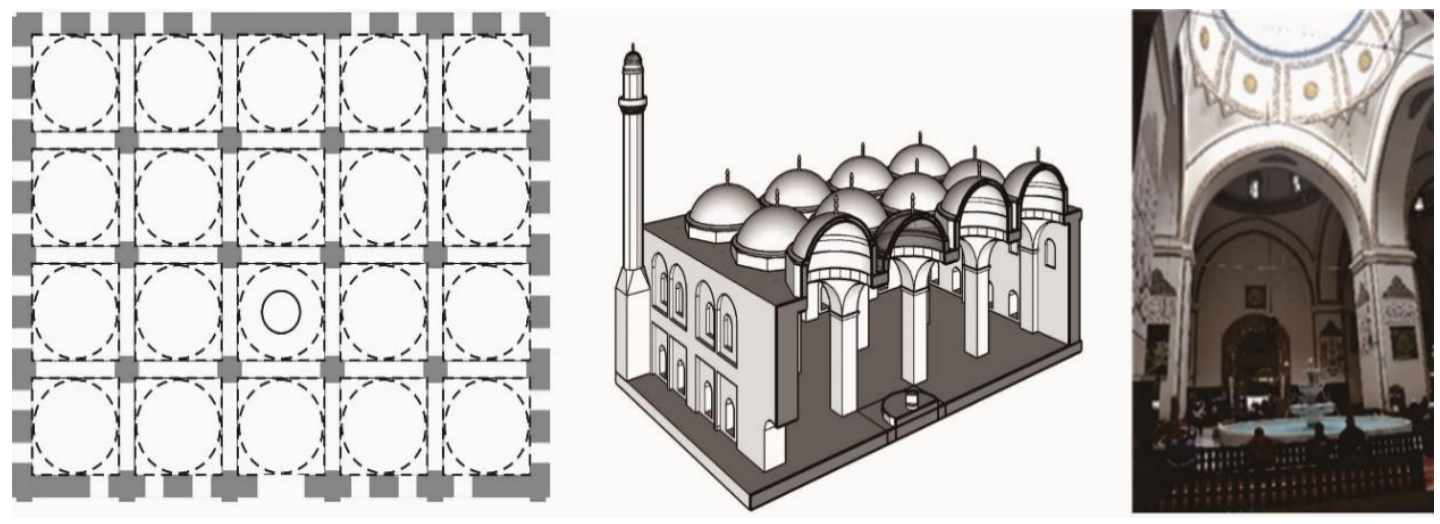

Figure 4. Bursa Ulu Camii plan with 25 parallel domes, interior configuration, and small-enclosed courtyard with a fountain 


\subsection{Edirne Mosques}

The Capital Edirne (1369 to 1453) was the continuation of Bursa as the power reached across the continent. At least five mosques have characterized the architecture, which are Eski Camii (1402), Muradiye Cami (1435), Üç Şerefeli Camii (1438), Bayezid Kulliye Cami (1484) and Selimiye Camii (1568). Though situated in Edirne, the last two are excluded from the pre-Istanbul style. These mosques were built in the peak of the dynasty in the classical period.

The two mosques in the early Edirne era are similar to the Bursa period, where the great mosque has a repetitive dome, and the other utilizes few domes by the opposite T-plan. Edirne Eski Camii is similar to the Bursa Ulu Camii for using the parallel dome but different in number. Instead of 20, the nine similar domes host the main prayer hall in nearly homogenous repetition. The minor variation takes place in the type of pendentive between the nine dome units. Except for its fountain, the atmosphere of Bursa Ulu Camii can easily be found inside the mosque, which is characterized by the repetitive arches and columns. Muradiye Camii (1435) represents another essential type of Bursa's mosque, the reverse T-plan with four domes (figure 5). Similarly, with Yildirim Bayezid and Yesil Camii,Muradiye Cami uses three domes in the forward-facing area where a single dome covers mihrab-front space in the back. The opposite Tplan mosque denotes small to medium mosques where the dome level is not yet significantly different.
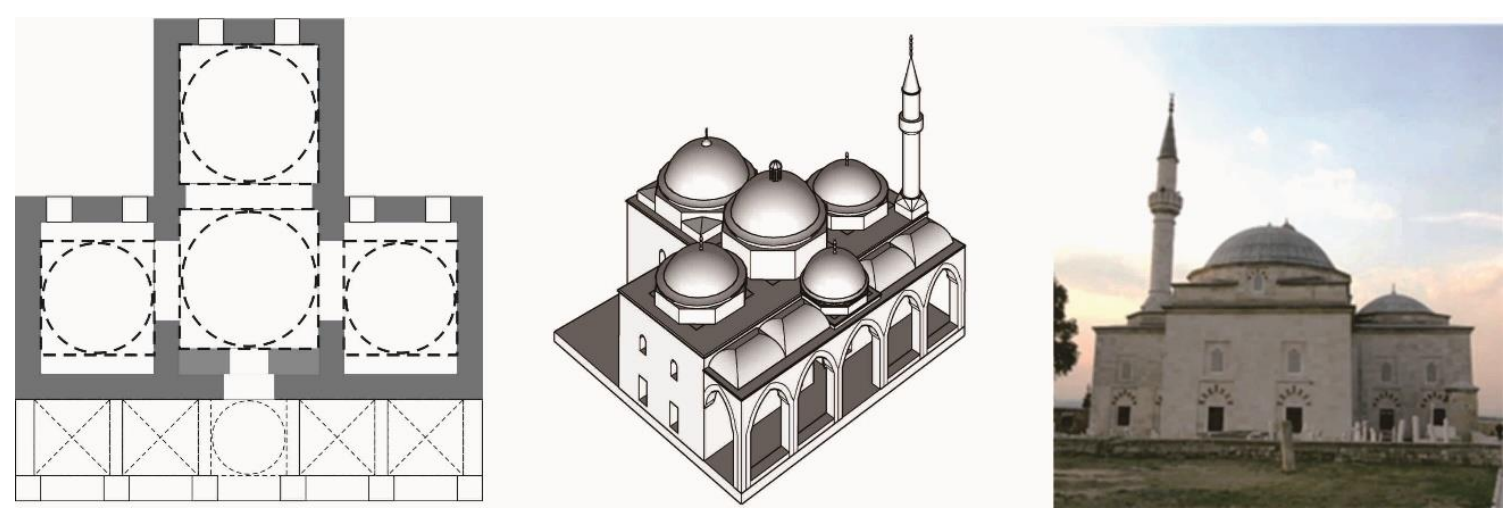

Figure 5. Muradiye Mosque with three domes on the Opposite T-plan and the side elevation (photo: Alidost Ertuğrul)

Üç Şerefeli Camii (1438) conveyed the progressive development from the repetitive to the centralized dome much before the conquest of Istanbul. Beside it re-utilizes the courtyard for the first Ottoman's mosque (Kawamoto, 2015), it also employs the central big dome with four secondary domes in the right and left sides as the first majorminor combination dome arrangement. The central dome was the widest in its era with 24 meters, which is supported by two primary columns inside and four others in a hexagonal frame. The two columns beside bear the significant dome also support the minor domes (figure 6). The central dome, which is slightly above the level of the secondary dome, creates more massive interior space. The dome arrangement is unique and never been applied for other previously-dated mosques; thus, it became a key-pattern for further development. 

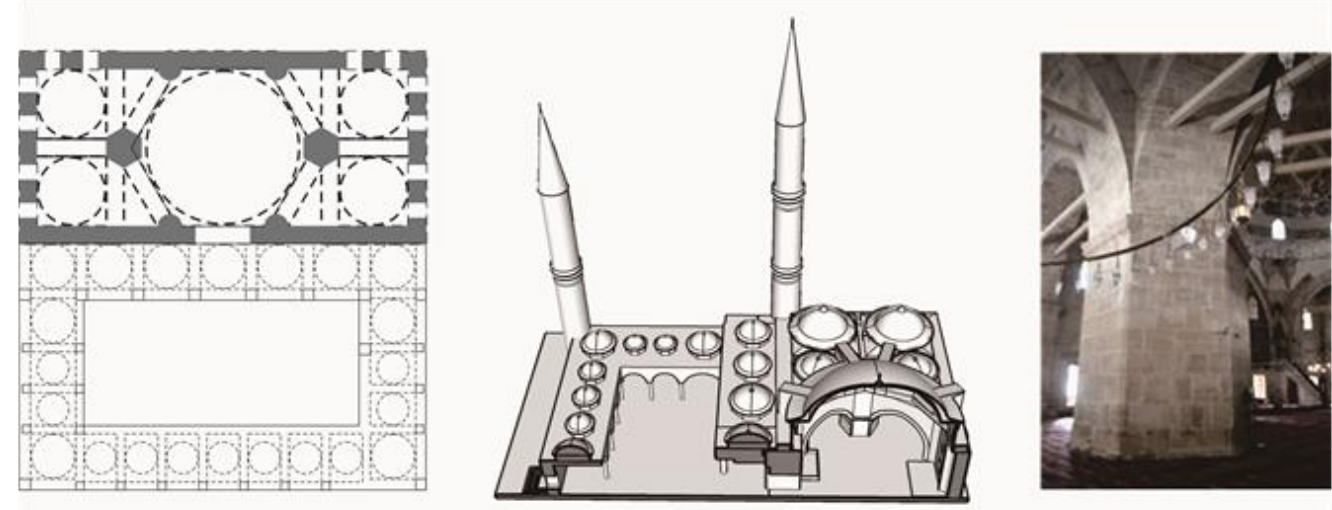

Figure 6. Üç Şerefeli Camii plan, section, and the giant hexagonal column support the hexagonal main frame and front elevation

\subsection{Byzantine Churches}

Before going deeply to the mosques in Istanbul, where dome architecture was also already existed, the understanding of the basilica's architecture is noticeable. In Constantinople era, a basilical typology exists much before Christianity, particularly in Greece and Rome as a part of Forums and Agoras as a form of a social building. Dome buildings built before and after Hagia Sophia (537) such as Küçük Ayasofya Camii or known before as the Church of the Saints Sergius and Bacchus (527), Hagia Irene (532), and Zeyrek Camii or Monastery of the Pantocrator (1118) convey their architectural characteristics. Most of the basilicas have an elongated-cross plan with the barreled-base dome construction in the main hall and cross vaults surrounding. If compared to the Ottoman's domes, the drum-base of the domes are taller and filled with higher lofty openings.

The structural system of Hagia Sophia lies on the central dome supported by two half domes and several cross vaults in both sides' galleries. The structure was distinctive, not only in terms of the most prominent church with the widest dome but also different from most of the basilica in the Byzantine era (Diker, 2016). It is even broadly believed that it was under the architectural influences of the Middle East (Plachý, Musílek, Podolka, \& Karková, 2016). According to Semavi Eyice it neither has precedent nor followers (Eyice, 2002). The dome is the vanity as long as its weakness. It was damaged in 557, and Isidore the Younger increased the dome's arch up to sixth meters and 46 ribs to prevent further collapse and found a small-significant improvement to avoid displacement (Oto \& Hara, 2017).

Meanwhile, it is also suspected that the high loft with the tall opening was one of the causal factors in collapsing the central dome under earthquake. The further dome replacement is also believed that it had been down-leveled to anticipate an intricate swing on the very wide antique dome (Diker, 2016). Besides the significant repairmen and displacements on the dome, further additional construction for side buttresses and four minarets were added to twig the structure during the Ottoman era.

\subsection{Istanbul Mosques}

Istanbul is the last capital of the empire from 1453 to 1922. As a result of the Constantinople takeover, Sultan Mehmet II did not directly construct a new mosque. He firstly converted Hagia Sophia to be an Islamic prayer place in the first Friday praying. It became a subject of the Ottoman convention as a "Fethiye Camii" or Conquest Mosque. Five years later, Eyüp Sultan Camii (1458) was built and became the first and most important mosque for the Dynasty in Istanbul. Unfortunately, the original structure of the Eyüp was ruined in the earthquake and rebuilt in 1798 with a Baroque style correspond to the reconstruction era in the $18^{\text {th }}$ Century. 


\subsubsection{The missing link of the Istanbul mosques.}

As the first mosque in Istanbul, the previous Eyüp Sultan Camii was linking the mosque architecture through the Dynasty. Ekrem Hakkı Ayverdi clarifies that the original Eyüp was a smaller structure with a centralized dome accompanied by two half domes on the left and right sides, and completed by a courtyard (Ayverdi, 1953; Numan, 2019). The main structure was a further resemblance of Üç Şerefeli Camii by the replacement of minor domes in the left and right sections with half domes (figure 7). The expansion of the main prayer hall in parallel with the mihrab wall satisfies the importance of the first raw in prayer. Completed with a dome just in front of the mihrab and space enlargement on both sides, it reminded its origin in Central Asia. It obviously represents the continuous tradition of side chambers of iwan, as found in Bursa T-type.
Another important aspect of the old Eyüp was the revak, which strengthened the pre-Istanbul hypostyle by the double-layered dome configuration surrounding the courtyard. Üç Şerefeli Camii was the first mosque that reutilizes the inner court after absent in Bursa. Nevertheless, the old Eyüp Sultan Camii even brought back the yard more massively in Istanbul after the conquest. It had told much about how the architectural chain from the previous culture was developed. It is fascinating since the structure was precisely built just after the Constantinople conquest. Instead of copying the Hagia Sophia, the general configuration even laid back to the Seljuk type, where the hypostyle space with a large court surrounded by revak was the characteristic. It is an obvious fact that this mosque was very important not only because of its history and strategic role as a coronation place of the Ottoman but also for its architectural role.

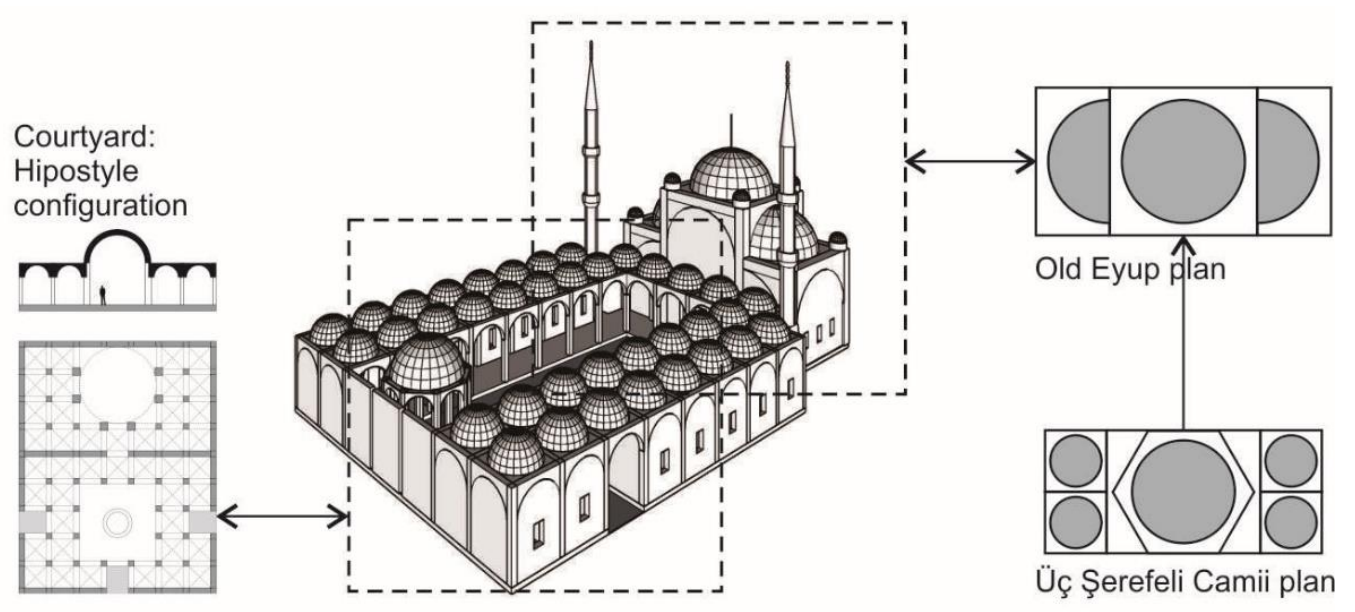

Figure 7. The Old Eyüp with two half domes in left and right wings represented the continuation of Üç Şerefeli Camii spatial arrangement, and the revak was reminding the hypostyle pre-Istanbul mosques.

The other early mosque, Eski Fatih Sultan Camii, then was built five years after the Eyüp in 1463 as the biggest kulliye in the Ottoman time. Architect Atik Sinan designed the first sultan mosque dedicated to the Fatih Sultan Mehmet with relatively different neither with Hagia Sophia nor Eyüp Camii. The original Fatih mosque was on the square plan with a central dome supported by a single half-dome on the mihrab area and three additional minor domes on each left and right sides (Ayverdi, 1953) (figure 8). The mihrab area which was ordinarily covered by a dome, replaced by a half dome. This arrangement perhaps either aimed for a bigger mihrab space or as iwan representation on the mihrab orientation. The dome configuration was never applied before in the pre-Istanbul periods and acted as another link to the further dome architecture in Istanbul. 

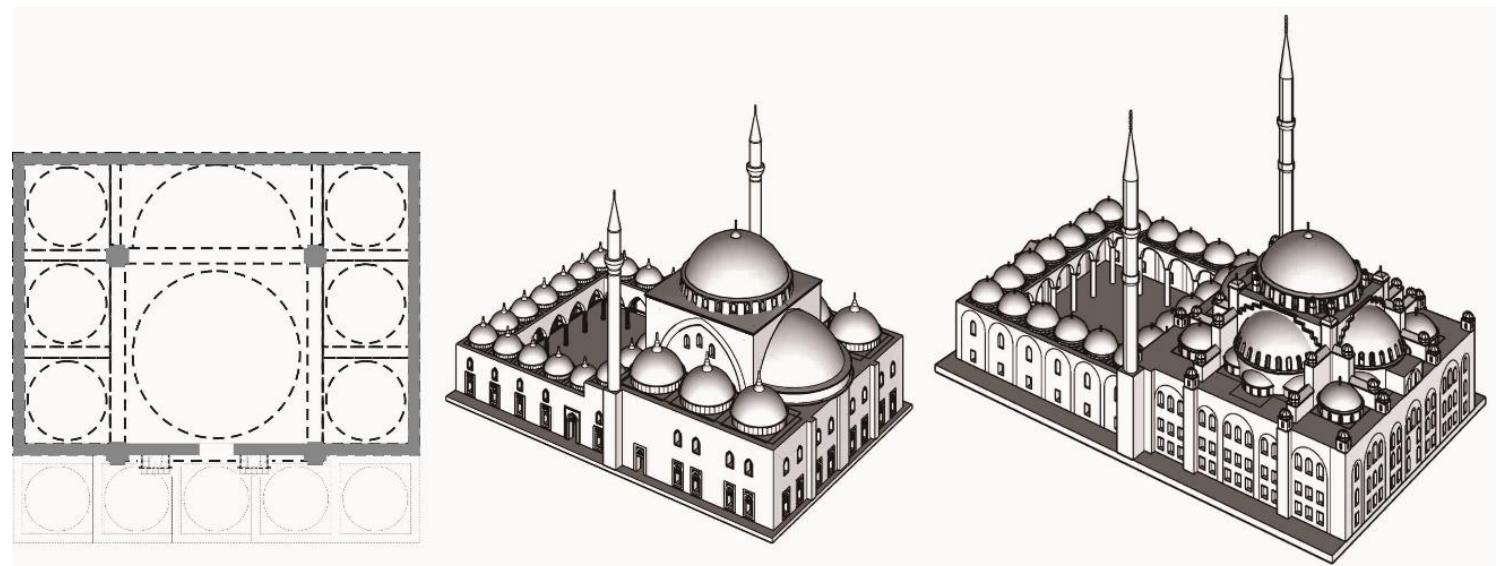

Figure 8. The main plan of Eski Fatih mosque the original central structural system with one half-dome (1463) and with four half domes (1771)

\subsubsection{The popularity of the four half domes}

Eski Fatih Sultan Camii suffered from nine powerful earthquakes through the Ottoman's history and unluckily fallen its dome in 1509 and 1766 (Fahjan \& Keypour, 2006). It was also reported damaged in the four other incidents, and the original style was then alternated (Berilgen, 2007). These unsymmetrical domes are also probably one of the main factors that lead to the collapse of the building beside the geological factors (Dark \& Ozgumus, 2002). Experiencing an unbalanced asymmetrical configuration of the old Eyüp and Eski Fatih, the new Fatih was built completely different in 1771 with four half domes to support the central dome. Unlike the previous arrangement, which seems not cohesively distributing the loads, the four half domes help the structure transfer the load both vertically and horizontally as a pyramid.
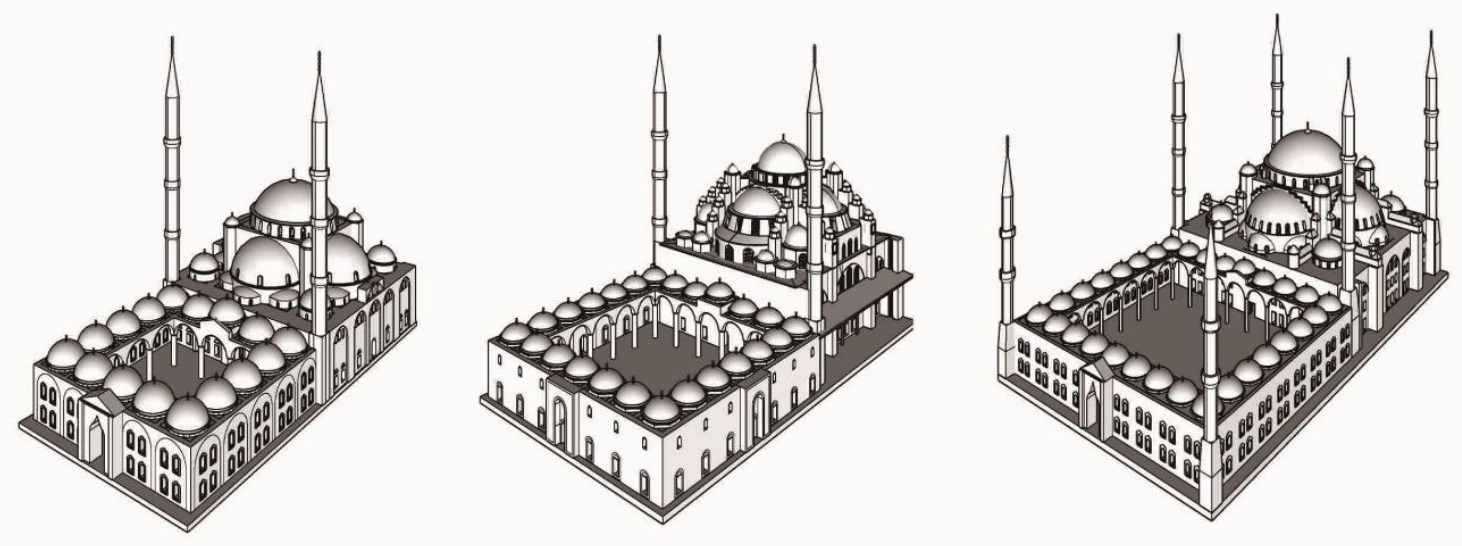

Figure 9. The four half domes mosques; Sehzade, Yeni Camii, and Sultan Ahmet

The four half domes on four arches configuration were dominant, which was applied by many magnificent mosques in Istanbul. Besides the New Fatih, there are many four half-dome mosques such as Şehzade Camii (1543), Yeni Camii (1597), and the Blue Mosque of Sultan Ahmet Camii (1609) (figure 9). Even the modern great mosque of Camlica (2019) is also utilizing this structural form. This configuration creates a spatial verticality but, at the same time, increases the lateral rigidity. The monumentality is achieved, the air ventilation is optimized, and the daylighting is maximized. 


\subsubsection{The lessons learned from Hagia Sophia}

Bayezid II Camii (1501) and Süleymaniye Camii (1550) also employ the four arches as the mainframe of the central structure. However, these mosques are only applying two half-domes on the two arches and leaving the others with the openings to lite more the main prayer hall. The main configuration is reminding the central structure of Hagia Sophia, although the structural and interior qualities are not equal. The architect Hayreddin utilized the configuration in Bayezid II, and fifty years later, Mimar Sinan also applied it for the Great Mosque of Süleymaniye. The three differences are obviously observable (figure 10).

Süleymaniye mosque, as one of the most excellent works of Sinan as well as the dynasty, encompasses the exciting design features. The Süleymaniye is the biggest mosque in the era with all its architecture properties by dome spans for 26.5 meters and 53-meter-high. Although the primary structural system seems identic to Hagia Sophia with the four-barrel vault carrying system, the central dome, it also represents the typical Asian Turkish configuration. The rest configuration belongs to its own such as the hierarchical domes surrounding for the lateral support acting like a pyramid. Beside fond in the structural system, the Süleymaniye is also better for more open and spacious prayer hall with optimum daylighting, air ventilation, acoustic, and structural system (Almughrabi, Prijotomo, \& Faqih, 2015). In the opposite, Hagia Sophia is struggling the structural deficiency, daylighting insufficiency, and ventilating glitches (Saoud, 2004).

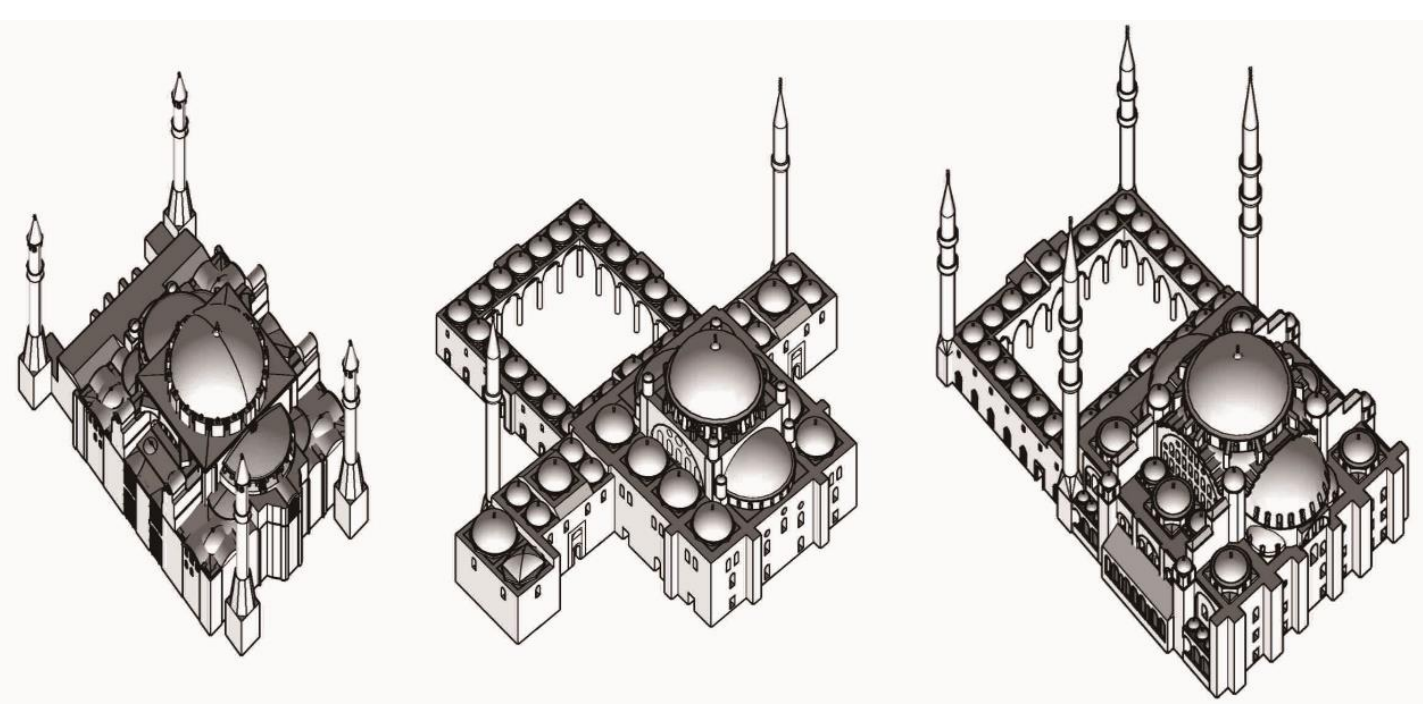

Figure 10. The Hagia Sophia, Beyazid II, and Süleymaniye mosque

\subsubsection{The asymmetrical experiment of Sinan}

Although getting a lesson from the failure of Eski Fatih Camii from the asymmetrical structure, Architect Sinan had a kind of experimental design applying a different approach to Mihrimah Camii Üsküdar (1543). Instead of using one or two, he accessed the three half-domes and left only one arch open with the window on its square supporting frame (figure 11). Despite its irregular configuration, the Mihrimah proofs its stability from many earthquakes. The Mihrimah Üsküdar is the lonely three half-dome configurations discovered in this study. Again, this three half domes mosque acts as another link for the comprehensive development of the dome architecture. 

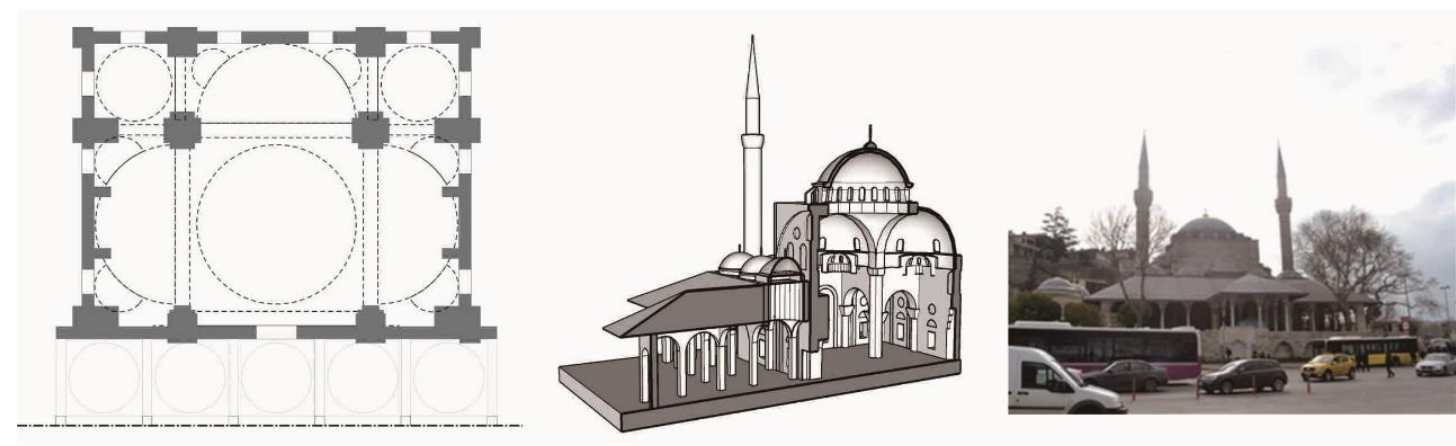

Figure 11. The three half-dome of Mihrimah Uskudar, section, and elevation

\subsubsection{The rise of the main single dome configuration}

Bayezid Külliyesi Camii (1484) is the small mosque as part of a kulliye located in Edirne employs a single dome on the four arches supported by pendentives. The dome configuration is quietly effective since the structure is more straightforward, and space can be maximized. It is followed by Yavuz Selim Camii (1520) and lately by Mihrimah Camii Edirnekap1 (1563). By using the same principles, Haseki Sultan Camii (1538) stepped forward with twins' dome, which enlarged its eight pendentives turns to half-dome-alike or squinches on the four corners in every dome.

The popularity of the single main dome mosque seems inspired by its structural simplicity and enlarged space. The mosque may extend the dome dimensions through its geometrical base, which turns to be hexagonal or octagonal. Mosques are accessing a hexagonal frame such as Sokollu Mehmed Pasha (1556) and Atik Valide Camii (1571) with some minor half-domes to support the central dome. The squinches of the Sokullu, which transformed back to a half-dome, seems inspired Mimar Sinan to figure out the four half-dome-alike to support the biggest dome of the Selimiye (see figure 12). The late mosques such as Yeni Valide Camii (1708) and Eyüp Sultan Camii, which rebuilt in 1798 , also utilize this configuration.
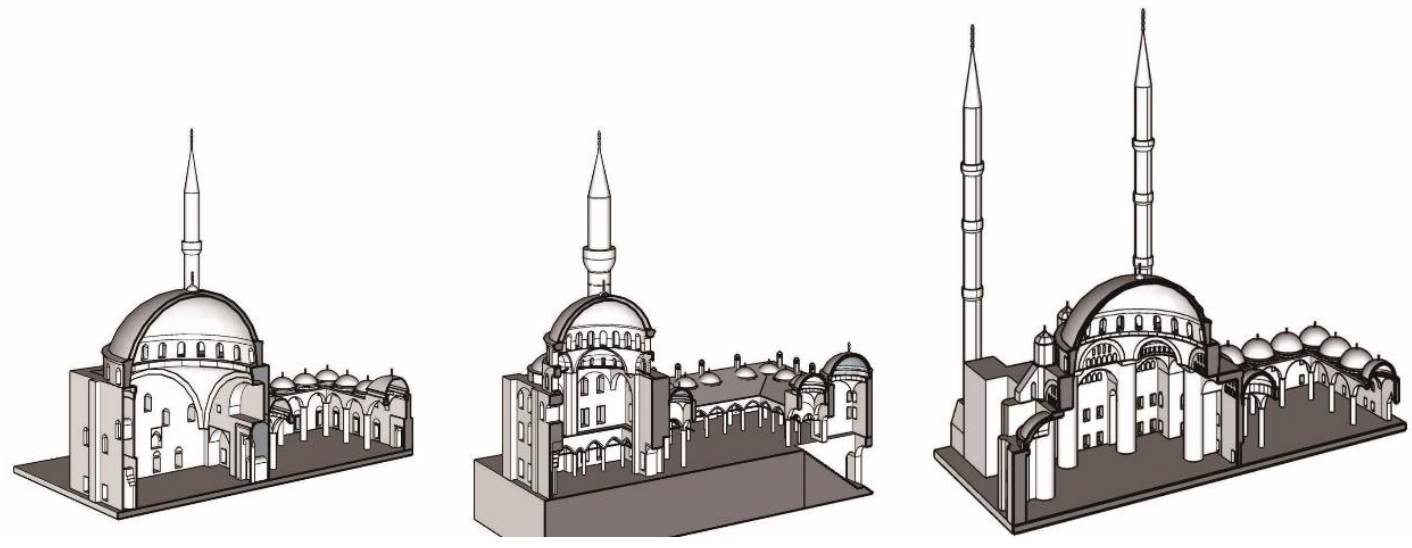

Figure 12. The single central dome Yavuz Selim Camii (tetragonal), Sokullu Mehmed Pasha (hexagonal), and Selimiye Camii (octagonal) 
Selimiye Camii (1568) then became the most magnificent dome in the empire with 31.25 meters span on the octagonal frame designed by Sinan. Besides utilizing the four half-domes and four open arches to support the main structure, the four minarets are also acting as a counterbalance. The spires were used only as mosque signage in the courtyard corners in the Süleymaniye case. Before his masterpiece went to be a reality, Sinan seems practiced the extended octagonal frame in Rüstem Pasha Camii (1561).

\subsection{Dome configuration development in the Ottoman mosques}

From the examination, there are only three dome typologies in general; repetitive domes, centralized domes, and single dome. These three have further options depending on the complexity of the construction (figure 13). The repetitive domes aim at the use of multiple dome units from several to many, either in a similar or different size. The single dome focuses on a single-central dome with-further supporting system as pendentives, squinches, or minor half-domes. The centralized domes mean for the use of the central dome supported by half-domes on its side(s). Some mosques are also under the two categories since they represent both groups or as a transitional form. Edirne Uc Serefeli Camii is both for the repetitive and centralized domes, and some of the polygonal frame mosques such as Selimiye is both in single and centralized domes.

The repetitive dome mosque was familiar for the great mosques in the pre-Istanbul period characterized by using the repetition of a dome unit with the tetragonal arch-frames. The mosque might have nine or twenty domes with similar size. All these domes occupy the same level of roof platform, creating homogenous-modular space inside. A large number of columns and arches dominate the prayer room, creating a hypostyle atmosphere. Seljuk's great mosque is familiar with this arrangement and somehow has affected some mosques in the earlier time of the dynasty in Bursa and Edirne without an open courtyard. Bursa Ulu Camii (1396) and Edirne Eski Camii (1402) are among other famous older magnificent mosques using these repetitive domes solution. The iwans which were familiar in the courtyardhypostyle Seljuk architecture turned to be more compacted and ended with inner iwans. Mosque's courtyard went to be diminished (e.g., Manisa mosque), transformed to be inside fountain (e.g., Bursa Ulu Camii), and left to the only light dome (e.g., Edirne Eski Camii). Nonetheless, the iwan still existed directing the gate, the four-axis surrounding the fountain, and in the form of the mihrab half dome decorated by muqarnas. 


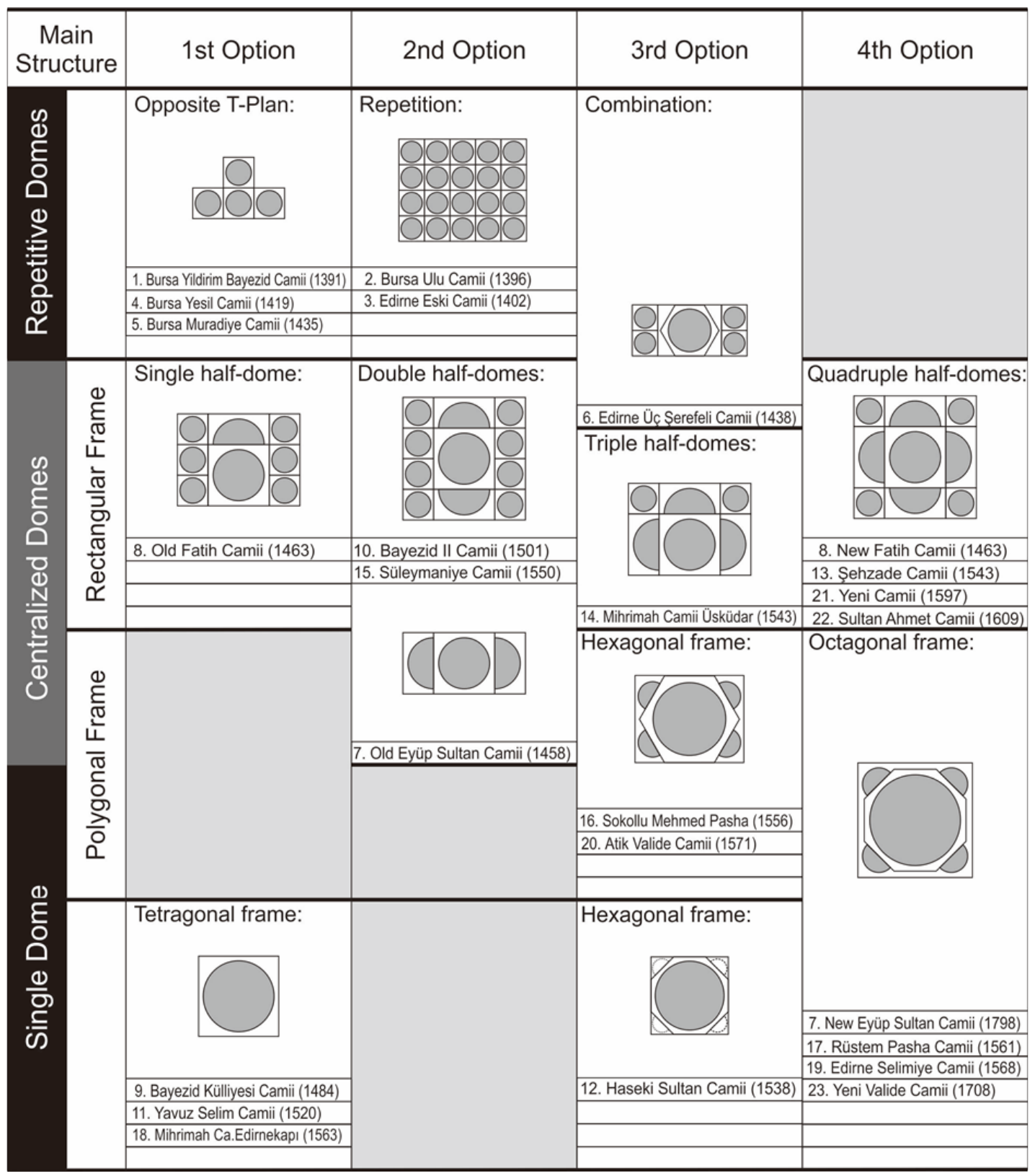

Figure 13. Dome types and development in the early Ottoman Mosques

The repeating dome also formed the reverse $\mathrm{T}$ plan, known as 'Bursa type,' for the smaller mosques. The domes cover three different functions as the central hall, mihrab-front hall, and side chambers representing iwan in both wings. There is no column presents between the spaces but the wall. The size of the center domes is usually more prominent than the iwan's domes. This style was popularly employed in significant mosques such as Bursa Yildirim Bayezid Camii (1391) and Bursa Yesil Camii (1419).
Interestingly, after the Istanbul conquest, this dome-type has not vanished but evolved in a suitable way by merging with half dome style. The old Eyüp and Eski Fatih proved this argumentation. In the old Eyüp, the two half domes on the left and right side performed the iwan rather than basilica's half dome style. This was why this first mosque in Istanbul did not copy the Hagia Sophia with its front and rear half domes instead. The iwan is also used for mihrab for qibla direction shown by the half dome with muqarnas in the former mosques. For this reason, 
the single half dome in the imam area characterized the old Fatih mosque. Once again, this was another evidence that the Ottoman did not apply the Hagia Sophia configuration directly.

The repetitive dome thus evolved to be a centralizing dome and resulted in the combination of dome size in the late Edirne period. Üç Şerefeli Camii (1438) involves an assortment of the central dome and the secondary domes surrounding. Though it accessed a horizontal dome arrangement or non-pyramidal configuration, like its predecessor, the big main dome has created a central space which never been applied before. The secondary domes are added on both sides to enlarge the functional space by repeating smaller dome as in the hypostyle mosques. The reappearing courtyard was also brought the mosque back to the Seljuk tradition though the function might be different. The following great mosques in the Ottoman era then utilize the courtyard covered by arcade (revak) as prayer space extension.

The Istanbul period was initiative characterized by the old Eyüp mosque and Eski Fatih mosque and crowned by the Suleymaniye mosque in the Ottoman peak. The centralized mosque then became popular applied for almost great mosques in Istanbul. The mosques custom elevated domes with the central supporting system by half-domes and arches in its sides, which also aim for space expansion. The level of the central dome is higher than the supporting construction surrounding creating a pyramidal-like structure. The domes step down to the edge of the prayer hall, configuring a structural system aimed at both gravitational and lateral loads. The repetitive smaller domes might be added to the external space nearby. The supporting construction surrounding will act as the buttresses to support the central dome from depletion and earthquake. By this arrangement, the mosque will have a monumental space inside as well as a formal appearance outside. The daylight, as well as fresh air, are easy to pass through openings in the domes and walls.

The centralized dome is supported by a tetragonal or polygonal frame characterized by the form of the base on its central structure. It defines the number of columns applied. The four-side frame is very popular, starting from the oldest mosque of the old Fatih Camii to the newest mosque of Sultan Ahmet Camii, and replayed by Camlica Camii. The optional variety of this type is by the amount of the half-dome applied from one, two, three, and four on its sides. The other sub-type of the centralized dome is by employing the polygonal frames with a hexagonal or octagonal form. Several extents of the half-domes are also supporting the central dome from the main arches in the polygons.

The two half-domes, as found in Hagia Sophia, is only applied in Bayezid II and Süleymaniye. Although it was used for the greatest mosque in Istanbul, none of the further construction utilized the style. A single half-dome was also available. Unfortunately, it could not stand to the earthquake as the first version of the Fatih mosque, which was altered by the four half-domes in 1771. The Ottoman architects developed a more lateral supporting system with the four half-domes acting as buttresses in its four sides. Although theoretically, it will decrease the quantity of daylight, number opening in the cubes and the walls have resolved the problem as we found in the recent Fatih or Sultan Ahmet mosque. The Süleymaniye, with two half-domes and two arches in its primary structural system, however, is even much stronger than the recent Fatih (Fahjan \& Keypour, 2006). Nevertheless, the soil amplification under the earthquakes was suspected as the most causal affecting the failures (Berilgen, 2007).

The application of the single dome mosque is also interesting since it comprises large range mosques in the country. Zal Mahmut Pasha Camii (1577) in Uskudar as the small mosque and the high dome of Mihrimah Sultan Camii (1563) in Edirnekapi that Mimar Sinan designed both are found constructed by a single dome in its main hall. The advantage of this method is mainly in the spacious space under the central dome since it free from the columns and the optimum openings placed on its cube and taller walls. An extension space may be added next to the mainframe with several minor domes, as found in the Bayezid Kulliyesi mosque.

A single dome mosque also employs the tetragonal, hexagonal, or octagonal arches-frame supported by four, six, or eight columns without the supporting half-dome surrounding. A 
tetragonal-framed dome uses pendentives in its four corners in a simple form, carved as stalactite, or constructed as a half-dome-alike of squinch. A more prominent single dome mosque is possible by alternating the pendentives with squinches in its corner; thus, the mosque's square plan will have 12 columns with four arches and four halfdomes. Haseki Sultan Camii (1538) is an example of the single rectangular plan with the octagonal frame employing squinches.

The single dome became popular and lately been developed for the application of magnificent mosques, thus transformed into the singleenlarged dome. The enlarging space with the halfdomes of squinches on the main arches comes in several ways. The optional base is either a tetragonal, hexagonal, or octagonal frame. Sinan discovered this type in 1556 by Sokollu Mehmed Pasha Mosque and designed many others afterward. The building integrity increases by more additional squinch's half-domes as well as arches were resulting in the possibility to enlarge the dome size. The Selimiye Camii, the masterpiece of Sinan, was developed by this opportunity as the largest dome in the Ottoman era. Four arches and four squinch's half-domes supported the central dome with the help of eight small flying buttresses surrounding. Sinan also applied a similar approach for Atik Valide Camii (1571).

From the side of Architect Sinan's works, evolution is also fascinating. Sinan tried all the possibilities of the Istanbul type from the single dome and centralized with a tetragonal or polygonal frame within all available varieties. For the single dome, he already started with the evolution of 'new style' by using the half-domealike of squinches for replacing the pendentives in Haseki Sultan Camii (1538). The octagon then returned the tetragonal frame on the same square plan of the mosque, which never been practiced before. However, he back to a 'simple' single dome with four pendentives on Mihrimah Camii Edirnekap1 (1563), which is more prominent in the central dome. For the centralized domes with a tetragonal frame, Sinan also surprised us with initiating a fully four half-dome in Şehzade Camii (1543), then continuing with the three half-domes on Mihrimah Camii Üsküdar (1543), and ending up with the only two half-domes on the great Süleymaniye Camii (1550). For the polygonal frame, again, he discovered the new improvement by initiating a hexagonal structure with four halfdomes for Sokollu Mehmed Pasha (1556), then following by an octagonal frame with four halfdomes for Rüstem Pasha Camii (1561) and Edirne Selimiye Camii (1568), and closing with a hexagonal with five half-domes in Atik Valide Camii (1571).

\section{CONCLUSION}

The reinterpretation of dome architecture in the Ottoman mosques had appeared under the influence of many different cultures from central Asia to Europe. The dome evolution shows an exciting development starting from pre-Istanbul age to the peak of the empire, which tied each other by visible architectural links. The medieval Turk of Karakhanids and Ghaznavids in the $9^{\text {th }}$ and $10^{\text {th }}$ centuries were the sources of architectural origin by the central dome, chambers, and courtyards surrounded by multi columns structure of hypostyle and iwans. Along with the development of civilization, architecture have evolved by several combinations and adjustments according to the available knowledge and resources.

Bursa T-type mosque and repetitive dome composition are the initial articulation of the empire to the more progressive dome architecture. The Turk firstly adopted the Seljuk courtyard to smaller court in Anatolian Seljuk then incorporated it inside the mosque. The inner court in these types later evolved to a fountain under one of the domes, and iwans turned to chambers on both sides. The iwan that used to be constructed by vault was then alternated by a dome. The two left and right-wing in the Bursa Ttype act as iwan chambers with still show arches inside. While for the repetitive domes on the magnificent mosques, the iwan merged in the four rooms on the fountain sides in Bursa Ulu Camii or daylighted dome without a fountain in Edirne Eski Camii. These arrangements inspired further enlarged dome of Üç Şerefeli Camii, where the central dome is more prominent, the side cambers thus divided as an alternative of the iwan, and an open courtyard reappeared after a while absent. The Üç Şerefeli further subsequently inspire the next mosque generation.

After the Constantinople conquest, the first mosques in Istanbul shows the significant link from the previous, the existing, to the next architecture. The old Eyüp Camii and Eski Fatih 
Camii indicate the adoption of the prior tradition of the centralized dome with iwans combined with the separated court surrounded by revak. The iwan, which used to appear with vault or dome, now turned to be a half dome. Though supporting the central dome by a square base with barrel vaults was known to Turks since Central Asia, the old Eyüp and Eski Fatih half domes structurally might be inspired by Hagia Sophia but in term of spatial organization and purposes are entirely different. After 48 years of the conquest, Bayezid II Camii in 1501 finally took a similar configuration of the Hagia Sophia. These links, however, could not be seen from the present Eyüp and Fatih mosques since they were rebuilt further corresponding to the architecture of the late era.

Instead of directly imitating the basilica's architecture, they have alternated with some significant adjustments in a long process of evolution. The vertical characteristic of basilica's roof with the elongated plan seems not matching directly with the Ottoman mosques. The two halfdome and two opening arches yet transformed into one of the Ottoman's masterpieces as great mosque of Süleymaniye Camii, after 97 years of adjustments and modification by Sinan. Several deficiencies of Hagia Sophia, as well as the failures of the old Eyup and Eski Fatih, have inspired the architects to reinforce immensely the central dome. Instead of one or two half-domes, a four-half-dome then applied to secure flattened wide dome and to stand with the lateral force from an earthquake. The four half-domes thus became a simplified arrangement for many magnificent mosques in the Ottoman's time.

For the smaller mosques, the development of the single-centralized dome is also exciting. A single dome structural system has also transformed from a simple square frame to a tetragonal, hexagonal, or octagonal central dome. The modification of the pendentives to the squinches as half-domealike and later to half dome transfer the circular base of the corners enlarging the space. The tetragonal bottom thus turns to be a more prominent hexagonal or octagonal frame is the unique solution to extend the single dome arrangement. Numerous mosques from small to grand mosque of Selimiye as one of the remarkable designs of the Ottoman's architects have used these simple-enlarged single domes.

The dome architecture in the Ottoman's peak time had involved a broad range of methods as a result of the civilization. The eastern and western culture in the building has met in the age resulting in very rich architectural legacies, which became a considerable contribution to the dome architecture. The Ottoman architects have proven that their works have a deal with the techniques and contexts, resulting in the evolution of mega dome architecture where many splendid solutions had been generated.

\section{ACKNOWLEDGMENT}

This paper was supported by a research grant of Universitas Islam Indonesia under the scheme of International Research Collaboration 2019/2020 in partnership with Fatih Sultan Mehmet University Istanbul.

\section{REFERENCES}

1. Almughrabi, N., Prijotomo, J., \& Faqih, M. (2015). Suleymaniye Mosque: Space Construction and Technical Challenges. International Journal of Education and Research (Vol. 3). Retrieved from www.ijern.com

2. Ayverdi, E. H. (1953). Osmanl Mimarasinde Fatih Devri-III (1st ed.). Istanbul.

3. Berilgen, M. M. (2007). Evaluation of local site effects on earthquake damages of Fatih Mosque. Engineering Geology, 91(2-4), 240-253. https://doi.org/10.1016/J.ENGGEO.200 $\underline{7.02 .001}$

4. Almughrabi, N., Prijotomo, J., \& Faqih, M. (2015). Suleymaniye Mosque: Space Construction and Technical Challenges. International Journal of Education and Research (Vol. 3). Retrieved from www.ijern.com

5. Ayverdi, E. H. (1953). Osmanl Mimarasinde Fatih Devri-III (1st ed.). Istanbul.

6. Berilgen, M. M. (2007). Evaluation of local site effects on earthquake damages of Fatih Mosque. Engineering Geology, 91(2-4), 240-253. https://doi.org/10.1016/J.ENGGEO.200 $\underline{7.02 .001}$

7. Dark, K., \& Ozgumus, F. (2002). New evidence for the Byzantine Church of the 
Holy Apostles from Fatih Camii, Istanbul. Oxford Journal of Archaeology, 21(4),393-413.

https://doi.org/10.1111/1468$\underline{0092.00170}$

8. Diker, H. F. (2016). Ayasofya ve onarimlarl (1st ed.). Istanbul: Fatih Sultan Mehmet Vakıf Üniversitesi Yayınları.

9. Eyice, S. (2002). Presentetion in Osmanlı Mimarisi Sempozyumu. Ankara: Kubbealtı Akademisi Kültür ve Sanat Vakfi.

10. Fahjan, Y. M., \& Keypour, H. (2006). Effects of Dome System on the Seismic Behaviour of Ottomans Historical Structures. In P. B. Lourenco, P. Roca, C. Modena, \& S. Agrawal (Eds.), Structural Analysis of Historical Constructions. New Delhi.

11. Gamm, N. (2014). Eyüp Mosque, the Ottomans' 'coronation' mosque. Retrieved June 26, 2019, from http://www.hurriyetdailynews.com/eyu p-mosque-the-ottomans-coronationmosque-70472

12. Güngör, I. H. (1987). The Dome in Sinan's Works. Environmental Design: Journal of the Islamic Environmental Design Research Centre, 1(2), 156-167. Retrieved from https://s3.amazonaws.com/media.archne t.org/system/publications/contents/4367 /original/DPC0743.pdf?1384785273

13. Idham, N. C. (2017). Arsitektur Abad Kejayaan, Belajar dari Turki (1st ed.). Yogyakarta: Trans Tekno.

14. Johns, J. (1999). The "House of the Prophet" and the Concept of the Mosque. In J. Johns (Ed.), Bayt Al-Maqdis, Jerussalem and Early Islam (1st ed., pp. 59-112). Oxford: Oxford Studies in Islamic Art. Retrieved from https://www.academia.edu/6014749/Th e_House_of_the_Prophet_and_the_Con cept_of_the_Mosque

15. Karamağaralı, H. (2002). Türk Cami Mimari'sinde Mekan Gelişmesi ve
Ayasofya Mes'elesi. In Osmanl Mimarisi Sempozyumu (pp. 83-108). Ankara: Kubbealtı Akademisi Kültür ve Sanat Vakfi.

16. Kawamoto, S. (2015). Courtyards and Ottoman mosques in the 15th and 16th centuries: Symbolism, mimesis and demise. $\quad I T U \quad A \mid Z, \quad 12(2), \quad 35-48$. Retrieved from http://www.az.itu.edu.tr/azvol12no2web /06-Kawamoto-1202.pdf

17. Kuban, D. (1985). Muslim Religious Architecture, Development of Religious Architecture in Later Periods. Leiden: E.J.Brill.

18. Kuban, D. (2007). Osmanli Mimarisi (1st ed.). Istanbul: YEM-Yayin.

19. Kuran, A. (1968). The Mosques in Early Ottoman Architecture. (W. R. Polk, Ed.) (1st ed.). London.

20. Mustafa, F. A., \& Hassan, A. S. (2013). Mosque layout design: An analytical study of mosque layouts in the early Ottoman period. Frontiers of Architectural Research, 2(4), 445-456. https://doi.org/10.1016/J.FOAR.2013.0 8.005

21. Necipoğlu, G. (2005). The Age of Sinan: Architectural Culture in the Ottoman Empire (1st ed.). Hongkong: Reaktionbooks.ltd.

22. Numan, I. (1982). Anadolunun Fethinden Istanbulun Fethine Türk Tekke ve Zaviye Mimarisi. Ankara University.

23. Numan, I. (2019). Eyyûb Sultan'a Bir Ziyâret Arkasında/n. Kubbealti Akademi Mecmuasi, 190(48/2).

24. Oto, A., \& Hara, T. (2017). Structural Characteristics of Hagia Sophia under Consideration of the Ribs Inside the Dome. Procedia Engineering, 171, 797804.

https://doi.org/10.1016/J.PROENG.201 7.01.366

25. Plachý, J., Musílek, J., Podolka, L., \& Karková, M. (2016). Disorders of the 
Building and its Remediation - Hagia Sophia, Turkey the Most the Byzantine Building. Procedia Engineering, 161, 2259-2264.

https://doi.org/10.1016/J.PROENG.201 6.08 .825

26. Reyhan, K., İpekoğlu, B., \& Böke, H. (2013). Construction techniques of domes in some Ottoman baths. Journal of Cultural Heritage, 14(3), e35-e40. https://doi.org/10.1016/J.CULHER.201 2.11.019

27. Saoud, R. (2004). Muslim Architecture under Ottoman Patronage (1326-1924).
(Lamaan Ball, Ed.). Manchester UK: FSTC Limited. Retrieved from http://www.fstc.co.uk

28. Sözen, M. (1975). Türk mimarisinin gelişimi ve Mimar Sinan. Istanbul: Türkiye İş Bankası Kültür Yayınları.

29. Taib, M. Z. M., \& Rasdi, M. T. (2012). Islamic Architecture Evolution: Perception and Behaviour. Procedia Social and Behavioral Sciences, 49, 293-303.

https://doi.org/10.1016/J.SBSPRO.2012 .07 .027 